\title{
PENERAPAN JAVASCRIPTY REACT UNTUK APLIKASI CHAT ROOM BERBASIS WEB
}

\author{
Fahmi Nuralamsah ${ }^{1}$, Muhamad Nurdin $^{2}$, Fitri Sya'bandyah ${ }^{3}$, Peti Savitri ${ }^{4}$ \\ 1,2,3,4 Prodi D3 Teknik Informatika, Universitas Sangga Buana YPKP Bandung \\ ${ }^{1}$ korespondensi: nuralamsah.fahmi@gmail.com
}

\begin{abstract}
The chat room application is the result of development of information and communication technology. It allows users to discuss in a room or a group of chatting which can be accessed anywhere and everywhere and using any devices (mobile or computer). The purpose of this research is to develop a chat room application using React.js and Javascript. The system development method used in this research is Prototype Method which is suitable for developing this application. The result obtained is the chat room application which can be integrated with other big application that need chat room application. In its development, React.js will handle the client and Javascript will handle the back-end or server assisted by other library.
\end{abstract}

Keywords: Chat room application, Chatting application, Web, React JS, Javascript.

\begin{abstract}
ABSTRAK
Aplikasi chat room merupakan hasil dari pengembangan teknologi informasi dan komunikasi. Aplikasi ini memungkinkan pengguna untuk berdiskusi dalam sebuah room atau group chatting yang bisa diakses dimanapun dan kapanpun dan menggunakan perangkat apapun (perangkat mobile atau komputer). Penelitian ini bertujuan untuk mengembangkan sebuah aplikasi chat room dengan menerapkan kedua teknologi tersebut. Metode pengembangan sistem yang akan digunakan adalah dengan metode pengembangan sistem Prototype yang dipa,ndang cocok dengan aplikasi yang akan dibuat. Hasil yang diperoleh adalah sebuah aplikasi chat room yang dapat digunakan atau diterapkan ke aplikasi lain yang lebih besar yang membutuhkan sebuah fitur chat room. Dalam pengembangannya, React.js akan berperan sebagai library di sisi klien dan Javascript akan beran di sisi backend atau server dibantu library lainnya.
\end{abstract}

Kata kunci: Aplikasi chat room, Aplikasi chating, Web, React JS, Javascript.

\section{PENDAHULUAN}

Dikutip dari laman datareportal.com, pada Oktober 2020 lebih dari 4 miliar orang di dunia menggunakan media sosial setiap bulannya dan hampir 2 juta pengguna baru bergabung setiap harinya. Dunia juga menghabiskan lebih banyak waktu di media sosial, dengan kepribadian pengguna saat ini, menghabiskan sekitar $15 \%$ waktunya menggunakan media sosial. Sedangkan media sosial yang paling banyak digunakan adalah Facebook dengan 2,7 miliar pengguna, Youtube dan Whatsapp dengan masing-masing 2 miliar pengguna, dan Facebook Messenger dengan 1,3 Miliar pengguna [1]. Data tersebut memperilihatkan bahwa aplikasi Whatsapp menjadi aplikasi chatting dengan pengguna terbanyak di dunia dibandingkan dengan aplikasi-aplikasi chatting lain seperti Facebook Messenger.

Sedangkan di Indonesia, dikutip dari bisnis.com , pada kuartal 3 tahun 2018 yang lalu, Statista melakukan studi tentang aplikasi chatting yang populer dan paling banyak digunakan di Indonesia, hasil dari studi tersebut menunjukan bahwa Whatsapp menjadi aplikasi chatting yang paling banyak digunakan di Indonesia dengan tingkat penetrasi sebesar $85 \%$. Disusul oleh Line dengan tingkat penetrasi 59\%, dan Facebook Messenger dengan tingkat penetrasi sebesar $49 \%$ [2]. 
Dari data-data diatas, dapat disimpulkan bahwa pengguna aplikasi chatting dan media sosial di dunia dan di Indonesia bisa dibilang sangat banyak dan masih terus bertambah.

Media sosial, terutama aplikasi chatting sudah menjadi kebutuhan masyarakat yang sangat penting. Sebagaimana yang dilansir oleh digitalcitizenship.nsw.edu.au bahwa berkirim pesan secara online dapat memberikan anak muda kesempatan untuk membangun skill sosial mereka dalam hal konteks formal dan informal. Berkirim pesan online dapat membantu anak muda untuk [3]:

1) Mengapresiasi berbagai bentuk perspektif.

2) Mengerti perbedaan perilaku mana yang pantas dan tidak pantas.

3) Menjadi komunikator non-verbal yang lebih efektif.

Aplikasi chatting terus berkembang menjadi lebih baik lagi seiring dengan kebutuhan pengguna yang juga meningkat dan seiring dengan perkembangan teknologi informasi dan komunikasi. Pengembangan aplikasi chatting akan terus mengikuti dan menggunakan teknologi-teknologi terbaru di masanya. Tujuan dari pengembangan aplikasi chatting atau chat room adalah untuk memudahkan pengguna untuk saling berkomunikasi. Dikutip dari sebuah jurnal yang berjudul "Instant Messaging and Social Neworks - The Advantages in Online Research Methodology", keuntungan atau manfaat dari menggunakan aplikasi chatting adalah [4]:

1) Mendukung pembelajaran di luar pengajaran berbasis kelas atau wawancara tatap muka.

2) Berkontribusi pada kemajuan teori dan praktek; akan membangun skill kognitif.

3) Mendukung dalam hal penyebaran informasi, membuat dan menjaga hubungan.

4) Memfasilitasi pembelajaran berbasis teman sebaya dan mandiri.

5) Nyaman untuk digunakan dan dapat diakses dari manapun. Hal ini menghemat waktu yang bersangkutan dengan penjadwalan interview tatap muka.

Pengembangan aplikasi chatting terus berkembang seiring dengan berkembangnya teknologi. Berdasarkan survey yang dilakukan oleh Stackoverflow pada tahun 2021 ini, React.js melampaui JQuery sebagai Web Framework yang paling banyak digunakan. React.js digunakan oleh $40,14 \%$ dari 67.593 responden, mengungguli 17 Web Framework lainnya seperti JQuery, Express, dan Svelte [5]. Sedangkan bahasa pemrograman yang paling banyak digunakan oleh profesional adalah Javascript. Javascript digunakan oleh $68,62 \%$ dari 58.031 responden dari seluruh dunia [5].

Berdasarkan latar belakang tersebut, penelitian ini bertujuan untuk mengembangkan aplikasi chat room yang dapat diterapkan pada aplikasi lain yang membutuhkan fitur chat room.

Ruang lingkup permasalahan yang akan dibahas pada penelitian ini adalah pengembangan aplikasi Chat room yang berbasis pada React JS dan dibatasi pada fitur chatting dalam group. 


\section{TINJAUAN PUSTAKA}

\section{React JS}

React atau ReactJs adalah Javascript library yang dibuat khusus untuk membantu para pengembang mambangun antar muka atau UI. Di dunia website dan aplikasi web, UI adalah koleksi yang terdiri dari menu, search bar, tombol, dan semua hal yang digunakan pengguna untuk berinteraksi dengan situs web atau aplikasi [6].

Sebelum dikembangkannya ReactJS, para pengembang cukup kesulitan dalam membangun UI menggunakan "Vanilla Javascript" (nama lain dari javascript mentah) atau menggunakan pendahulu React yang tidak terlalu fokus pada UI seperti JQuery. Hal ini membuat lebih lamanya waktu pengembangan dan berkemungkinan bersar terjadi banyak error dan bug. Jadi pada tahun 2011, teknisi Facebook, Jordan Walke membuat ReactJS khusus untuk meningkatkan pengembangan UI. Selain menyediakan React library yang dapat digunakan kembali (mengefisienkan waktu pengembangan dan memotong kesempatan terjadinya error), React hadir dengan dua fitur utama yang menambah daya tarik bagi para pengembang, yaitu JSX dan Virtual DOM.

\section{Web Application}

Web application atau aplikasi web adalah sebuah program komputer yang memfasilitasi web browser dan teknologi web untuk menjalankan perintah melalui internet [7].

Web application menggunakan kombinasi dari server-side scripts seperti PHP dan ASP untuk menangani penyimpanan dan mengambil informasi dan client-side scripts seperti Javascript dan HTML untuk menampilkan informasi tersebut kepada pengguna.

Pada dasarnya web application dibuat menggunakan bahasa yang disuport oleh browser seperti Javascript dan HTML. Terdapat beberapa aplikasi yang dinamis, membutuhkan server-side processing. Sebagian yang lain hanya web statis yang tidak membutuhkan pemrosesan di sisi server.

Web application membutuhkan server web untuk mengatur request dari klien, dari aplikasi server untuk menjalankan tugas yang di request, dan terkadang dari basis data untuk menyimpan informasi.

Berikut ini merupakan alur kerja web application:

1) Pengguna memicu sebuah request ke server web melalui internet, ataupun melalui web browser atau dari aplikasi antar muka pengguna.

2) Server web meneruskan request tersebut ke server web application yang sesuai.

3) Server web application menjalankan tugas sesuia dengan request, seperti mengquery basis data atau memproses data, lalu membuat hasil dari data yang diminta.

4) Server web application mengirimkan hasil tersebut ke server web dengan informasi yang diminta atau data yang sudah diproses.

5) Server web memberikan respon balik kepada klien dengan informasi yang 
diminta yang kemudia muncul pada tampilan pengguna.

Banyak keutungan yang akan didapatkan ketika menggunakan web application. Dibandingkan dengan aplikasi berbasis Desktop, aplikasi berbasis web menawarkan banyak keuntungan bisnis. Aplikasi ini dapat diakses dari semua komputer melalui internet, dibandingkan dengan harus menginstalkan pada setiap komputer. Berikut ini beberapa manfaatnya [8]:

1) Ketersediaan lintas perangkat

2) Kustomisasi untuk perangkat yang berbeda

3) Terintegrasi dengan sistem lain.

4) Lebih mudah untuk upgrade.

5) Menginkatkan fleksibilitas dan skalabilitas.

\section{Chatting}

Di dalam internet, chatting adalah berbicara pada orang lain yang menggunakan internet pada waktu yang bersamaan. Biasanya, yang dimaksud dengan "pembicaraan" disini adalah pertukarang pesan yang diketik yang membutuhkan sebuah situ web sebagai tempat penyimpanan pesan (atau "situs obrolan") dan sebuah kelompok pengguna yang mengambil bagian dari manapun di internet [9].

\section{Aplikasi}

Aplikasi, juga mengacu pada program aplikasi atau software aplikasi merupakan paket perangkat lunak komputer yang menjalankan fungsi spesifik secara langsung untuk pengguna atau, dalam beberapa kasus, untuk aplikasi lainnya. Sebuah aplikasi bisa berbentu self- contained program maupun kumpulan dari program-program [16].

Contoh dari aplikasi diantaranya ialah pengolah teks, program basis data, web browser, development tools, pengedit gambar, dan platform komunikasi. Aplikasi menggunakan operating system (OS) pada komputer dan program pendukung lainnya. Sebuah aplikasi menggunakan.

Aplikasi berbeda dengan perangkat lunak sistem (system software). Perangkat lunak sistem beroperasi di background dan tidak berinteraksi langsung dengan pengguna komputer. Aplikasi menggunakan system software untuk mengakses sumber daya perangkat keras standar seperti memory, storage, dan lain-lain.

\section{METODE}

Pengembangan aplikasi chat room berbasis web menggunakan metode pengembangan sistem Prototype. Dikutip dari jurnal yang berjudul "Model Prototyping Pada Pengembangan Sistem Informasi", protoyping adalah metode pengembangan sistem yang berupa model kerja dari sistem yang merupakan versi awal sistem [10].

Proses membuat sebuah prototype sangat interaktif dan repetitive yang mengkombinasikan tahapan pengembangan sistem tradisional. Prototype akan dievaluasi beberapa kali sebelum pengguna memutuskan bahwa prototype tersebut diterima. Tahapantahapan dari metode ini antara lain [11]: 
1) Analisis Kebutuhan Sistem

Analisis dilakukan untuk melihat berbagai komponen yang digunakan oleh sistem yang saat ini berjalan, termasuk perangkat keras, perangkat lunak, networks, dan sumber daya manusia.

2) Desain Sistem

Desain sistem mendeskripsikan apa yang yang sistem harus lakukan untuk memenuhi informasi yang dibutuhkan oleh pengguna. Desain sistem dapat dilihat sebagai desain antar muka, data dan proses dengan tujuan menghasilkan spesifikasi yang sesuai dengan produk dan metode antarmuka pengguna, struktur basis data dan prosedur pemrosesan dan pengendalian.

\section{3) Uji Coba Sistem}

Paket prototype perangkat lunak diuji coba, diimplementasikan, dievaluasi, dan dimodifikasi berulang-ulang hingga dapat diterima oleh pengguna. Uji coba sistem menargetkan pada pencarian error yang ada pada sistem dan membuat revisi dari sistem tersbut.

4) Implemntasi

Setelah prototype diterima, lalu pada tahap ini merupakan implementasi dari sistem yang siap dioperasikan kemudian terdapat proses mempelajari perbandingan sistem yang baru dengan yang lama, evaluasi teknis dan operasional serta pengguna, sistem dan interkasi teknologi informasi.

\section{HASIL DAN PEMBAHASAN}

Analisis Kebutuhan Pengguna

Kebutuhan pengguna aplikasi chat room terdiri dari kebutuhan fungsional dan kebutuhan non fungsional.

Dikutip dari sebuah jurnal yang berjudul " $A$ Novel Approach for Specifying Functional and Non-Functional Requirements using RDS (Requirement Description Schema)", Kebutuhan Fungsional mendeskripsikan fiturfitur kunci yang diinginkan dari sistem [12]. Sedangkan Kebutuhan Non-Fungsional, mengutip dari qracorp.com, Kebutuhan NonFungsional menspesifikasi tentang bagaimana sistem melakukan sesuatu. Kebutuhan nonfungsional tidak mempengaruhi dasar fungsionalitas dasar sistem (sebagaiman namanya, kebutuhan non-fungsional). Bahkan jika kebutuhan fungsional tidak terpenuhi, sistem akan tetap melakukan tujuan dasarnya [13].

a. Kebutuhan Fungsional

Berikut ini adalah kebutuhan fungsional dari aplikasi chat room:

1) Aplikasi harus dapat melakukan fungsi autentikasi seperti Sign in, Sign up, dan Sign out.

2) Aplikasi harus dapat menyimpan data pengguna. 
3) Aplikasi harus bisa menyimpan data group-group atau room-room .

4) Aplikasi harus bisa menyimpan data percakapan yang ada dalam group .

5) Aplikasi harus memiliki fitur untuk membuat group dan menambahkan anggota ke group tersebut.

b. Kebutuhan Non-Fungsional

Berikut ini adalah kebutuhan nonfungsional dari aplikasi chat room:

1) Aplikasi harus bisa berjalan secara real-time sehingga pesan yang tampil di satu pengguna sama dengan pesan yang tampil di pengguna lain di waktu yang bersamaan.

2) Aplikasi harus responsive yang artinya tampilan plikasi harus bisa menyesuaikan dengan ukuran layar divice tempat aplikasi ini dibuka.

3) Aplikasi harus dapat diajalankan di browser-browser yang umum digunakan oleh banyak orang seperti Chrome dan Firefox.

\section{Analisis Pengguna}

Pengguna yang menggunakan aplikasi chat room ini diharuskan memiliki pemahaman dasar tentang cara menggunakan aplikasi berbasis web, baik menggunakan komputer atau laptop maupun menggunakan perangkat mobile. Serta memiliki pemahaman menggunakan aplikasi chatting seperti Whatsapp atau yang lainnya.

Pengguna aplikasi chat room diberikan hak akses sebagai berikut:

1) Mengirim dan menerima pesan di dalam sebuah group.

2) Membuat group serta menambahkan anggota group kedalamnya.

\section{Perancangan Konseptual}

Mengutip dari jurnal yang berjudul “Conceptual Design”, perancangan konseptual merupakan kombinasi yang dimulai dengan definisi dan pemodelan desain produk dengan menggunakan konsep yang tepat dan netral yang berasal dari kebutuhan atau ide [14].

\section{a. Diagram Class}

Diagram class merupakan struktur statis yang menyajikan sebuah gambaran dari sistem dengan menspesifikasikan classclass dan relasi diantaranya. Gambar 1 dan 2 menggambarkan tentang class-class yang ada di sisi klien dan server. 


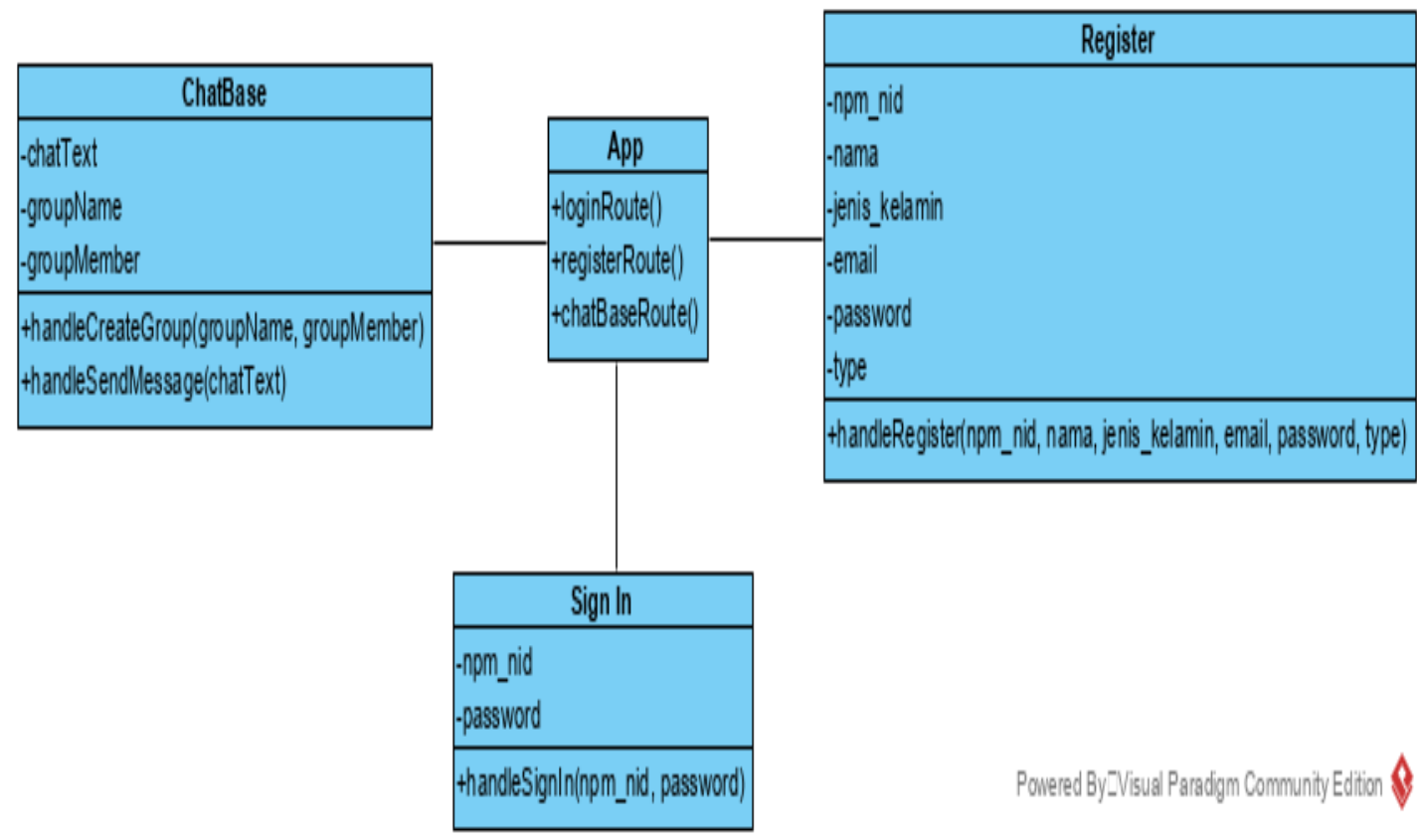

Gambar 1: Diagram Class Klien Aplikasi Chat room

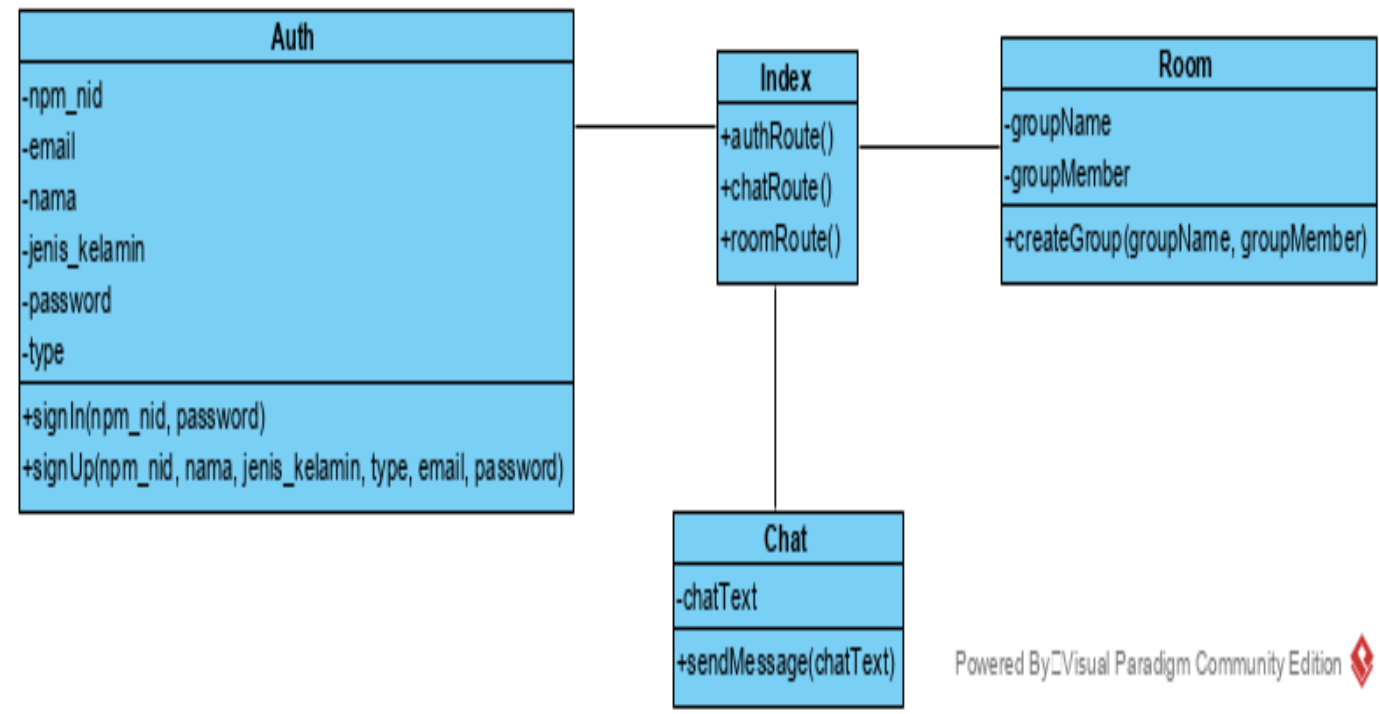

Gambar 2: Diagram Class Server Aplikasi Chat room

b. Diagram Deployment

Deployment Diagram merupakan diagram yang menunjukan konfigurasi dari runtime processing nodes dan komponenkomponen yang ada pada nodes tersebut.

Diagram deployment aplikasi chat room digambarkan oleh gambar 3 . 


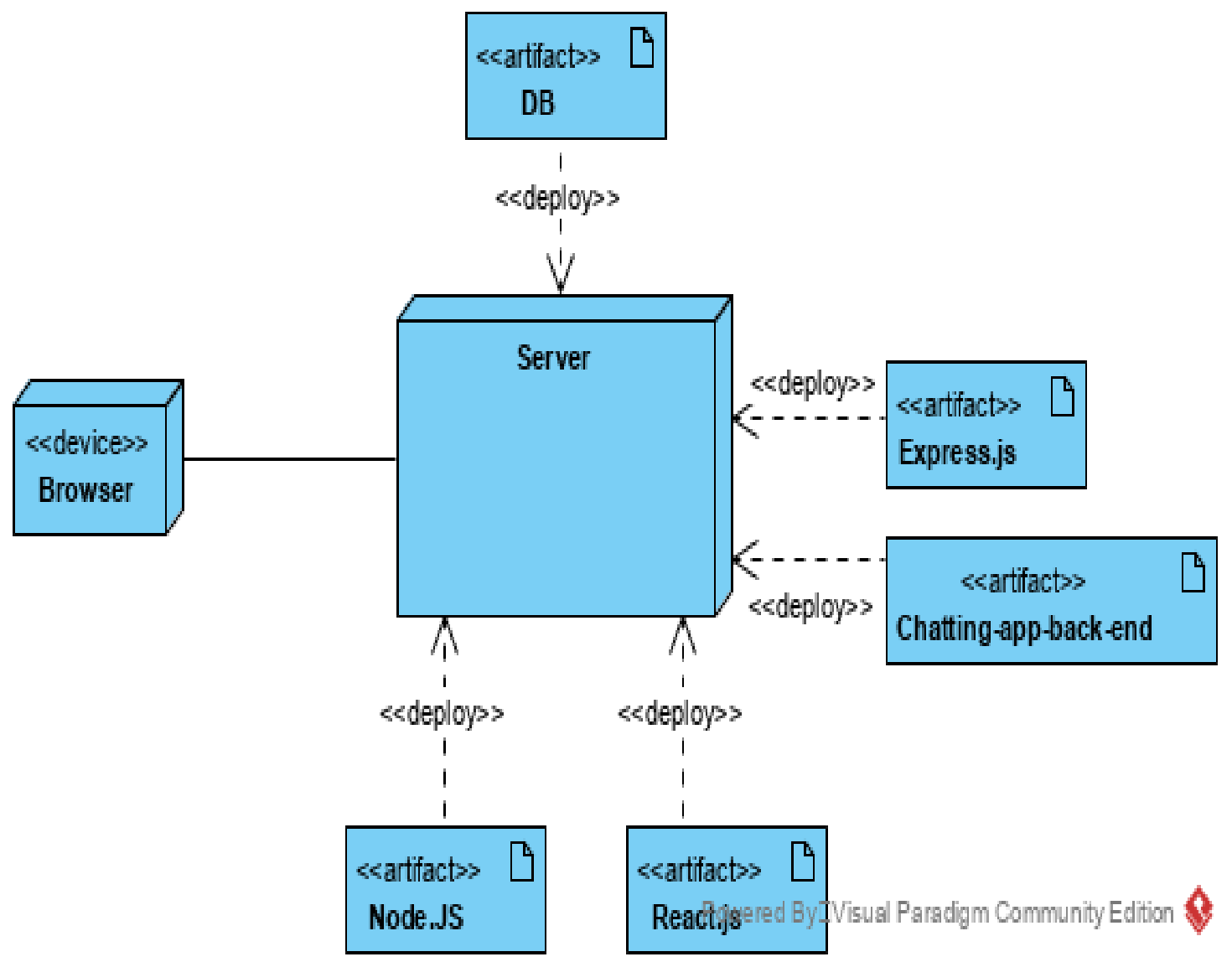

Gambar 3: Diagram Deployment Aplikasi Chat room

c. Uji Coba SistemTahapan uji coba sistem dilakukan untuk mendeteksi error, kesalahan-kesalahan pada saat pengkodean, dan kekurangan-kekurangan lainnya. Pengujian sistem yang dilakukan pada aplikasi ini menggunakan metode Black box testing. Black box testing merupakan metode pengujian perangkat lunak yang menguji fungsionalitas suatu aplikasi tanpa melihat kedalam struktur internal program.

Tabel 1 berikut ini adalah tabel yang berisi fitur-fitur pada aplikasi chat room yang diuji coba berikut dengan detail pengujiannya. 
ISBN 978-623-92199-2-5

Tabel 1: Tabel Uji Coba Sistem

\begin{tabular}{|c|c|c|}
\hline $\begin{array}{c}\text { Uji Coba } \\
\text { Fitur }\end{array}$ & Detail Pengujian & $\begin{array}{c}\text { Hasil } \\
\text { Pengujian }\end{array}$ \\
\hline Sign In & $\begin{array}{c}\text { Mengisi form login dan mengecek respon aplikasi } \\
\text { ketika email dan password tidak valid. }\end{array}$ & Berjalan baik \\
\hline Sign Up & $\begin{array}{c}\text { Mengisi form registrasi dan mengecek respon } \\
\text { aplikasi ketika terdapat form yang tidak valid. }\end{array}$ & Berjalan baik \\
\hline Create new & $\begin{array}{c}\text { Mengisi form untuk membuat group baru dan } \\
\text { mengecek respon sistem ketika terdapat masukan } \\
\text { yang tidak valid. }\end{array}$ & Berjalan baik \\
\hline $\begin{array}{c}\text { Send } \\
\text { message }\end{array}$ & Menuliskan pesan dan mengirimkannya di group. & Berjalan baik \\
\hline $\begin{array}{c}\text { Receive } \\
\text { message }\end{array}$ & Menerima pesan yang dikirimkan oleh user lain di & Berjalan baik \\
\hline $\begin{array}{c}\text { Logout } \\
\text { group. }\end{array}$ & Berjalan baik \\
\hline
\end{tabular}

\section{Perancangan Interface}

Desain interface atau antar muka ini menggambarkan halaman utama yang akan user kunjungi setelah berhasil login. Desain tersebut menggambarkan navigasi di sisi kiri halaman, tab group list, dan tampilan chatting dalam group.

Gambar 4 berikut ini merupakan desai interface dari aplikasi chat room yang dibuat. 


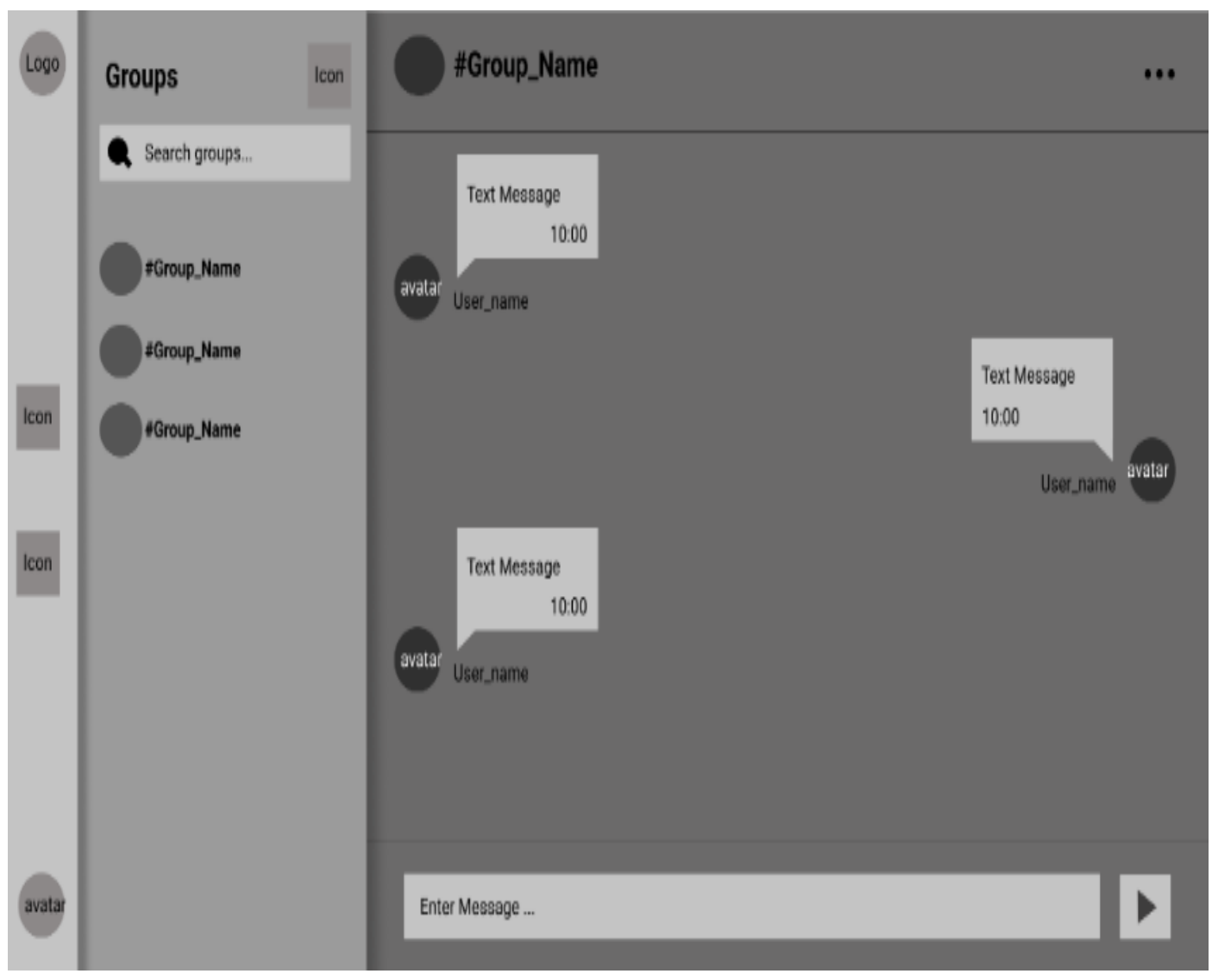

Gambar 4: Desain Interface Aplikasi Chat room

\section{KESIMPULAN}

Dari hasil penelitian ini, dapat disimpulkan bahwa :

1) React JS berperan sebagai library front-end yang mana memiliki fungsi untuk membuat semua komponen-komponen UI.

2) React JS lebih memudahkan pengembang untuk mengembangkan sebuah aplikasi web yang dinamis dan real-time seperti aplikasi chatting dibandingkan dengan menggunakan Vanilla Javascript.

3) React JS tidak dapat berdiri sendiri. React JS hanya menangani semua hal yang ada di front-end atau sisi klien dan untuk sisi server, diperlukan teknologi dan library lainnya.

\section{DAFTAR PUSTAKA}

[1] Simon Kemp, "Digital 2020: October Global Statshot," DataReportal-Global Digital Insights. https://datareportal.com/reports/digital2020-october-global-statshot (accessed Sep. 07, 2021).

[2] R. Mudassir, "Whatsapp Dominasi Chatting di Indonesia, Penetrasinya 83 Persen | Teknologi,” Bisnis.com, Jul. 02, 2019.

https://teknologi.bisnis.com/read/201907 02/84/1119199/whatsapp-dominasichatting-di-indonesia-penetrasinya-83persen (accessed Sep. 07, 2021).

[3] "What are the benefits of chat and messaging?," Digital Citizenship, 2019. 
https://www.digitalcitizenship.nsw.edu.a u/articles/what-are-the-benefits-of-chatand-messaging (accessed Sep. 07, 2021).

[4] K. O. Oseni, K. Dingley, and P. Hart, "Instant Messaging and Social Networks - The Advantages in Online Research Methodology," Int. J. Inf. Educ. Technol., vol. 1, no. Instant Messaging and Social Networks, p. 7, 2017.

[5] "Stack Overflow Developer Survey 2021,” Stack Overflow, 2021. https://insights.stackoverflow.com/surve y/2021/?utm_source=social-

share\&utm_medium=social\&utm_campa ign=dev-survey-2021 (accessed Sep. 09, 2021).

[6] S. Morris, "React JS-What is It? What is Used For? Why Should You Learn It? Skillcrush," Skillcrush. https://skillcrush.com/blog/what-is-reactjs/ (accessed Sep. 06, 2021).

[7] R. Gibb, "What is a Web Application? How a Web Application Works," What is a Web Application?, May 31, 2016. https://blog.stackpath.com/webapplication/ (accessed Sep. 06, 2021).

[8] Chairman, "The benefits of using webbased applications | Geeks Insights," Geeks, Dec. 20, 2019. https://www.geeks.ltd.uk/insights/thebenefits-of-using-web-based-applications (accessed Sep. 10, 2021).
[9] TechTarget Contributor, "What is chatting? - Definition from WhatIs.com," WhatIs.com, Apr. 2005. https://whatis.techtarget.com/definition/c hatting (accessed Sep. 06, 2021).

[10] Dwi Purnomo, "Model Prototyping Pada Pengembangan Sistem Informasi," JIMP - J. Inform. Merdeka Pasuruan, vol. Vol.2 No.2, pp. 54-61, Agustus 2017.

[11] Azhar Susanto and Meiryani, "System Development Method with The Prototype Method," Int. J. Sci. Technol. Res., vol. 8, no. 07, pp. 141-144, Jul. 2019.

[12] Tejas Shah and S V Patel, "A Novel Approach for Specifying Functional and Non-Functional Requirements using RDS (Requirement Description Schema)," Procedia Comput. Sci., vol. 79, pp. $852-$ 860, 2016.

[13] "Functional vs Non-Functional Requirements: The Definitive Guide," QRA Corp, Sep. 30, 2019. https://qracorp.com/functional-vs-nonfunctional-requirements/ (accessed Sep. 08, 2021).

[14] Francois Christophe, Eric Coatanea, and Alain Bernard, "Conceptual Design," SSARATHKUMAR, Jul. 2013, doi: 10.1007/978-3-642-20617-7. 